\title{
A note on facultative kleptoparasitism in Prionyx kirbii (Hymenoptera: Sphecidae) as a consequence of multi-specific shared nesting site, with description of its prepupa
}

\author{
Carlo Polidori, José Tormos, Josep D. Asís, Pau Mendiola \& Francesco Andrietti
}

Polidori, C., Tormos, J., Asís, J. D., Mendiola, P. \& Andrietti, F. 2006: A note on facultative kleptoparasitism in Prionyx kirbii (Hymenoptera: Sphecidae) as a consequence of multi-specific shared nesting site, with description of its prepupa. — Entomol. Fennica 17: 405-413.

Observations of a female of Prionyx kirbii at an aggregation of Stizus continuus revealed an alternative nesting behaviour of the first wasp due to the presence of the second one. The overlap of some resources (prey, kind of soil) allowed $P$. kirbii to act as a kleptoparasite of $S$. continuus. The observed female often re-used as nests pre-existing $S$. continuus emergence holes, but no $S$. continuus nests. The prey were obtained sometimes by stealing the grasshoppers from $S$. continuus nests and/or by attacking the females while carrying the prey. From a review of interspecific kleptoparasitism among sphecoid wasps it appears that family Sphecidae includes the highest number of facultative parasitism cases and this finding is discussed. In addition, the description of the prepupa of P. kirbii is given and is shown to be in agreement with the description of the mature larvae of the other species of the genus.

C. Polidori, Dipartimento di Biologia, Sezione di Zoologia e Citologia, Università degli Studi di Milano - Via Celoria, 26, 20133, Milan, Italy. Tel. +390250314795; E-mail: cpolidori@virgilio.it

J. Tormos, Unidad de Zoología, Facultad de Biología, Universidad de Salamanca-37071, Salamanca, Spain

J. D. Asís, Unidad de Zoología, Facultad de Biología, Universidad de Salamanca-37071, Salamanca, Spain

P. Mendiola, Departament de Zoologia, Universitat de València-c/Dr. Moliner, 50, 46100, Burjassot (València), Spain

F. Andrietti, Dipartimento di Biologia, Sezione di Zoologia e Citologia, Università degli Studi di Milano - Via Celoria, 26, 20133, Milan, Italy

Received 3 July 2004, accepted 13 December 2005

\section{Introduction}

Sphecoid wasps (Sphecidae and Crabronidae) often nest in large aggregations (e.g. Evans 1966 \& 1974, Evans \& Hook 1986, Rosenheim 1990). As the physical nesting requirements (like soil com- pactness, soil moisture and amount of vegetation among others), are similar in many cases for different species, nesting sites are often shared by a number of species. When this occurs, interspecific interactions may become frequent and lead to nest usurpation (Matthews 1983, Hook 
1987), kleptoparasitism (Kurczewski \& Spofford 1998, Casiraghi et al. 2003) or, more rarely, nest sharing (McCorquodale \& Thomson 1988). Facultative kleptoparasitism and brood parasitism (i.e. use by a wasp of another wasp's prey to feed her own brood) could have been an intermediate step in the evolution of the obligate kleptoparasitism and brood parasitism typical of genera such as Nysson and Stizoides (Evans 1966, Wcislo 1987).

In this paper we report a few observations taken on a single female of Prionyx kirbii (Vander Linden) (Hymenoptera: Sphecidae), a common species of the old world, nesting in the same area where a large aggregation of Stizus continuus Klug (Hymenoptera: Crabronidae) had been established for many years (Asìs et al. 1988 \& 2006). The behavioural consequences of the coexistence of the two wasps are analyzed.

Prionyx females usually establish their nests on bare, compact soil. The unicellular or, in few cases, multicellular nests are filled with Orthopthera Acrididae to feed the larvae. One grasshopper is usually provided to each larva (Evans 1958, Benz 1959, Bohart \& Menke 1976). Depending on the species, nests are constructed before or after hunting the prey. Some species close the nest temporarily before hunting (Evans 1958, Genise 1980, Grissell 1981). P. kirbii belongs to the group of species that dig the nest before hunting and make a temporary closure before the provisioning trip (Ferton 1902, Fabre, 1914, p. 202, Benz 1959, Bohart \& Menke 1976). P. kirbii females usually hunt one large prey, sometimes two, if they are too small (Benz 1959). There is only one report of Ferton (1902) of a nest with two cells, one with two-prey, the other with only one, but his finding is dubious. The nests structure consists of a vertical burrow from 3 to $4 \mathrm{~cm}$ deep followed by an horizontal section of about 4 cm (Benz 1959).

S. continuus females dig (multicellular) nests before hunting on bare and compact soil, provisioning them massively with grasshoppers (several for each cell). The nest remains closed during hunting flights (Asìs et al. 1988). The nest of $S$. continuus is composed of a main burrow (oblique to the soil surface) about $50 \mathrm{~cm}$ long from which 3-8 secondary tunnels depart, each of them ending in a brood cell. Generally $1-2$ acces- sory burrows (false nests $2-3 \mathrm{~cm}$ long, see Evans 1966) are dug close to the nest entrance (Asìs et al. 1988).

Our aims are twofold. Firstly, we report observations on an unusual strategy adopted by $P$. kirbii to obtain prey and nest; secondly, we describe the mature larva of $P$. kirbii, in order to provide traits to separate this species from others of the genus.

\section{Material and methods}

Observations were made on a single female of $P$. kirbii between 24.VI.2003 and 10.VII.2003, the date when the wasp was collected for determination. P. kirbii was observed on an aggregation of the solitary wasp Stizus continuus, in an area of salt-marsh (ca. $9 \mathrm{~m} \times 15 \mathrm{~m})$, characterized by a bare, compact soil, covered (30\% of the surface approximately) by Arthrocnemum fruticosum (L.) and Juncus maritimus Lam. and bounded by Pinus pinaster Aiton and Phragmites australis (Cav.). The female was marked with non-toxic paints to permit identification on field. Nests dug and provisioned by the wasp were marked with a coloured stick placed in the ground close to the entrances.

Observations on $P$. kirbii were made on a discontinuous base, since they were intermixed with a long term planned research on $S$. continuus.

In the following text, we will use the term "kleptoparasitism" to indicate when a wasp stole the host provisions from inside the nest and then carried them to her own nest or when she stole the host provisions attacking directly the host outside the nest; we will use the term "brood parasitism" if the wasp entered the host nest and oviposits on the host provisions, eventually eating the host egg.

The postdefecated larva (prepupa) was obtained at Saler, Valencia (6.IX.1992). The method employed to prepare the specimen, as well as the terminology of larval morphology and format used in the description follow fundamentally Evans (1987). The following abbreviations have been used in the description: $\mathrm{d}=$ diameter; $\mathrm{h}=$ height; $1=$ length and $\mathrm{w}=$ width. Voucher specimens are deposited at the "Torres-Sala" Entomological Foundation (Valencia, Spain). 
Table 1. Numbers of observations made on the female of Prionyx kirbii between 24.VI. and 10.VII.2003.

\begin{tabular}{|c|c|c|c|c|c|c|}
\hline Date & $\begin{array}{l}\text { Patrolling the area: } \\
\text { stopping on Stizus } \\
\text { continuus nests }\end{array}$ & $\begin{array}{l}\text { Patrolling the area: } \\
\text { "touching" S. con- } \\
\text { tinuus females }\end{array}$ & $\begin{array}{l}\text { Attacking } \\
\text { S. continuus } \\
\text { females on } \\
\text { on their nests }\end{array}$ & $\begin{array}{l}\text { Carrying } \\
\text { a prey to } \\
\text { a nest } \\
\text { their nests }\end{array}$ & $\begin{array}{l}\text { Closing } \\
\text { a nest } \\
\text { definitively }\end{array}$ & $\begin{array}{l}\text { Stealing a } \\
\text { prey from } \\
\text { S. continuus } \\
\text { females }\end{array}$ \\
\hline
\end{tabular}

\begin{tabular}{|c|c|c|c|c|c|c|}
\hline 24.VI. & 3 & & 1 & & & \\
\hline 25.VI. & 4 & 1 & & & 1 & \\
\hline 26.VI. & 2 & 1 & $1^{* *}$ & 1 & & $1^{* *}$ \\
\hline 27.VI. & & $1^{* \star *}$ & & & & \\
\hline 28.VI. & 4 & & & 1 & 1 & \\
\hline 29.VI. & 2 & & & & $1^{* * \star *}$ & \\
\hline 30.VI. & 2 & $1 * * *$ & & $1^{*}$ & & \\
\hline 01.VII. & & 1 & & & & \\
\hline 02.VII. & 1 & & & & & $1^{* * * * *}$ \\
\hline 03. VII. & 4 & & & 1 & 1 & \\
\hline 04.VII. & 3 & 2 & & & & \\
\hline 05.VII. & 5 & & & & & \\
\hline 06.VII. & 2 & & & & & \\
\hline 07.VII. & 2 & & & & & \\
\hline 08.VII. & 3 & & & & 1 & \\
\hline 09.VII. & 4 & & & & & \\
\hline 10.VII. & 1 & & & & & \\
\hline
\end{tabular}

* = prey carried deep in a grass area; nest not identified; ${ }^{* *}=$ prey stolen from the wasp after an attack; ${ }^{* \star}=$ the $S$. continuus female flown away after the "touch"; ${ }^{\star \star \star *}=$ this nest did not correspond to an emerging hole of $S$. continuus as the other ones; ${ }^{* \star * \star *}=$ prey stolen from inside the nest.

\section{Results}

\subsection{Behaviour of $P$. kirbii}

Table 1 summarizes the results of the observations. The female of $P$. kirbii was observed for the first time on the 24.VI.2003, while patrolling the nesting site of $S$. continuus, and she frequented the area every day of the observation period. The patrolling behaviour included always a number of stops on some nests of $S$. continuus (open or closed). The stops lasted 5-30 seconds and, on average, the wasp stopped on a nest 0.8 times/ minute (range: $0-5 \mathrm{~min}^{-1}, S D=1.31, n=19 \mathrm{ob}-$ servations that lasted more than 1 minute).

On some occasions (6 out of 42 contacts with the wasp) the Prionix female, while overflying a $S$. continuus nest when the owner was present at the entrance, flew rapidly down and "touched" the other wasp, disturbing her activity (in 2 cases out of 6 , the female of $S$. continuus flew away for a while after the "touch"). Three times the female of $P$. kirbii attacked more violently a $S$. continuus female as she was opening her nest to enter with a prey. One time she caused the abandonment of the prey by the attacked wasp: at this point the female of $P$. kirbii took the prey, stung it and transported it away, stopping sometimes to sting again the grasshopper. The other two times the female of $S$. continuus did not abandon the prey, and $P$. kirbii flew away. On another occasion, $P$. kirbii waited on a closed nest the return of the owner with a prey and followed her inside the nest, coming out a few seconds later with the grasshopper. Even in this case the wasp re-stung the prey during the transport. Neither females nor males of $S$. continuus showed any aggressiveness toward $P$. kirbii.

A total of 5 nests of $P$. kirbii were located in the nesting area of $S$. continuus, and 4 of them were identified as re-used emerging holes of $S$. continuus, but no nest of $S$. continuus was observed to be actively usurped by $P$. kirbii. A total of 4 prey-carryings by $P$. kirbii were observed, but no more than one to each nest. A fifth prey was carried in a peripheral area with dense vegetation, but the wasp disappeared in the grass and the nest was not found. Considering that the observed 5 nests were closed definitively by the wasp within one-two days since they were first recorded, and that the female was observed for a period of 17 days, probably many other unde- 


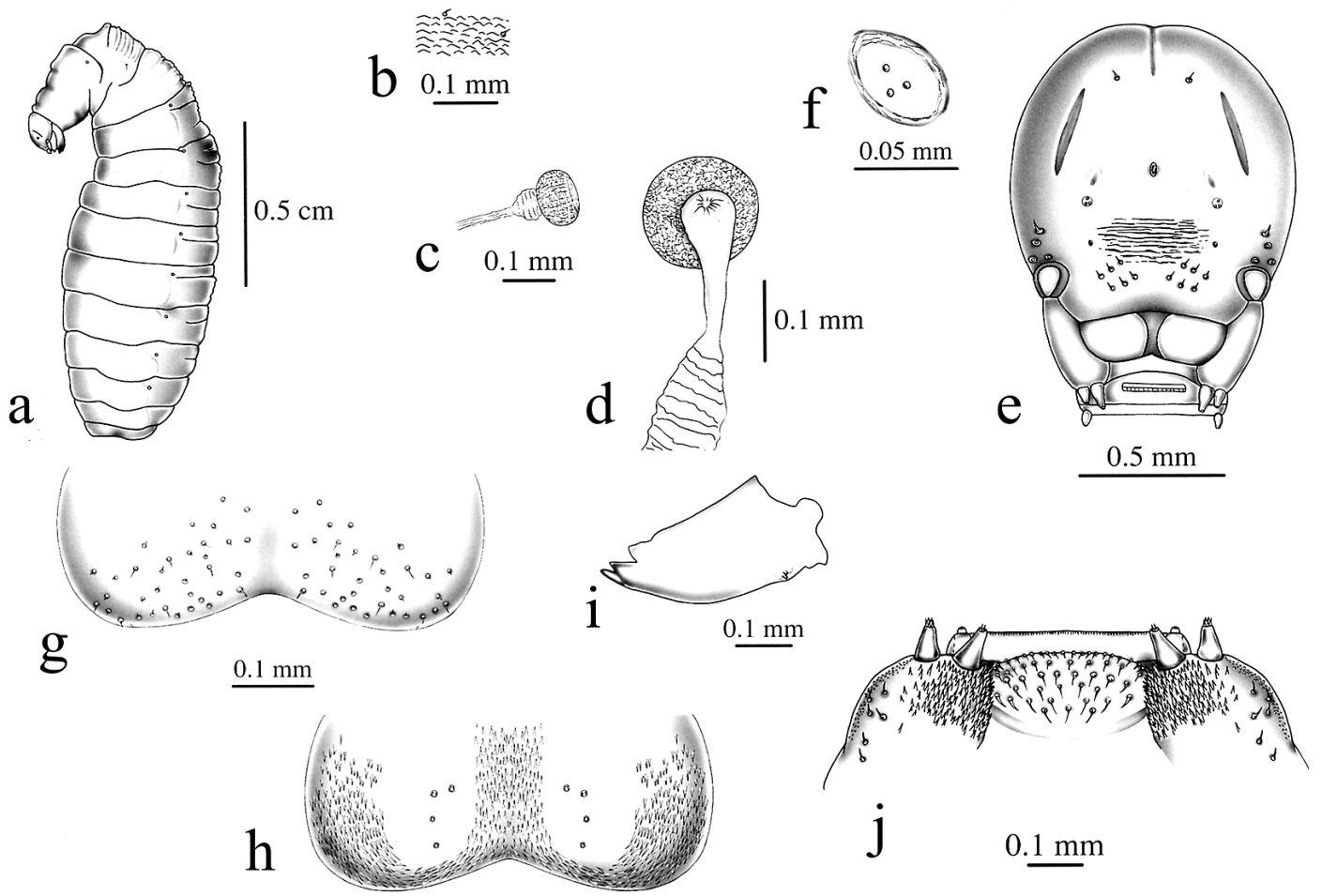

$0.1 \mathrm{~mm}$

Fig. 1. Prepupa of Prionyx kirbii (Vander Linden). - a. General aspect (lateral view). - b. Portion of integument. - c-d. Abdominal spiracle. - e. Cranium (frontal view). - f. Antennal orbit (frontal view). - g. Labrum. - h. Epipharynx. - i. Left mandible. - j. Maxilla and Labium.

tected nests belonging to the same individual were been present in the area.

\subsection{Description of the prepupa of $P$. kirbii}

General aspect (Fig. 1a). Body $(1=13.5 \mathrm{~mm}$, maximum $\mathrm{w}$ [3rd abdominal segment] $=4.3 \mathrm{~mm}$ ) hymenopteriform, elongate, strongly curved at the level of the third thoracic segment, with the thorax and first abdominal segment narrow with respect to the rest, yellowish, weakly sclerotized, except for spiracles. Anus terminal, a transverse slit. Pleural lobes convex. Integument (Fig. 1b) with large spinules ( 1 of spinules $=30 \mathrm{~mm}$, w basal $=10 \mathrm{~mm}$ ) arising from plate-like bases, with the exception of those of the thoracic segments (1 $=5 \mathrm{~mm}$ ) which are small and arranged in such a way that they have the appearance of transverse grooves, and with sparse setae $(1=3-7 \mathrm{~mm})$. Spiracles (Fig. 1c-d) all in a single line, on mesothorax, metathorax, and first 8 abdominal seg- ments; atria $(\mathrm{d}=\mathrm{ma})$ goblet-shaped; walls lined with ridges forming small and irregular polygons; opening into subatria armed with long spines; subatria comparatively small $(\mathrm{d}=64 \mathrm{~mm})$, with 6 swellings. Cranium (Fig. 1e) $(\mathrm{w}=0.9 \mathrm{~mm}, \mathrm{~h}$ [height measured to apex of clypeus] $=1.1 \mathrm{~mm}$ ) higher than wide, yellowish, with sparse setae $(1=$ $5 \mathrm{~mm}$ ) and some punctations close to mandibular insertion; vertex depressed medially; coronal suture and parietal bands present, brown; antennal orbits (Fig. 1f) $(58 \times 43 \mathrm{~mm})$ with membrane of the orbit convex, with 3 sensilla. Frons with five depressions, near epistomal suture and base of clypeus transversely furrowed; frontoclypeal suture unpigmented; clypeolabral suture well defined. Clypeus with 12 setae $(1=5 \mathrm{~mm})$. Labrum (Fig. $1 \mathrm{~g}$ ) (maximum $\mathrm{w}=470 \mathrm{~mm}$; maximum $\mathrm{h}=$ $150 \mathrm{~mm}$ ) bilobate; base smooth; anterior margin weakly pigmented with small sensilla; each lobe surface with sparse setae $(1=5 \mathrm{~mm})$ and dense conical sensilla $(\mathrm{w}=3 \mathrm{~mm})$; epipharynx (Fig. 1h) densely spinulose $(1$ of spinules $=25 \mathrm{~mm}$, basal $\mathrm{w}$ 
$=3 \mathrm{~mm}$ ) centrally and laterally, with 8 sensory pores $(\mathrm{d}=7 \mathrm{~mm})$ medially distributed en 2 epipharyngeal sensory areas, each with 4 pores.

Mouthparts. Mandibles (Fig. 1i) $(1=370 \mathrm{~mm}$, maximum $\mathrm{w}=170 \mathrm{~mm})$ robust, sclerotized, brown, teeth 3 and 4 dark brown, $2.2 \times$ as long as wide, with two punctures close to the basal external margin, with 4 apical teeth, 3 superior teeth on about the same plane, the basal tooth on a lower plane. Maxillae (Fig. 1j) with sparse lateral setae $(1=11 \mathrm{~mm})$, mesally densely spinulose, with very short spinules; maxillary palpi longer than wide $(75 \times 49 \mathrm{~mm})$ with 5 apical sensilla; galeae $(1=75$ $\mathrm{mm}, \mathrm{w}=30 \mathrm{~mm}$ ) similarly formed, with 2 large apical sensilla. Labium (Fig. 1j) setose (1 of the setae $=12 \mathrm{~mm})$; labial palpi longer than wide $(75$ $\times 49)$, with 4 apical sensilla $(\mathrm{d}=7.5 \mathrm{~mm})$; salivary orifice $(1=450 \mathrm{~mm})$ transverse.

\section{Discussion}

These are the first observations made on $P$. kirbii (as well as on the genus Prionyx) behaving as a kleptoparasite of a different species of sphecoid wasp, and provide new data on these interspecific relationships phenomena, which are probably more widespread than previously supposed among fossorial Hymenoptera. The observations are based on a single female. However, the behaviour is probably rare: in none of the 14 published works on the nesting habits of Prionyx spp. kleptoparasitic behaviour was detected (most important references quoted in the text; the complete list of works on Prionyx spp. could be found in Pulawski (1999)). For the much more investigated genus Ammophila, only in 4 out of more than 50 studies such behaviour was recorded (Table 2 and Pulawski 1999). This means that this behaviour is difficult to observe repeatedly. Accordingly, we consider this phenomenon worth of reporting in spite of the restricted data.

\subsection{The behaviour of $P$. kirbii on the nesting site of $S$. continuus}

The nesting behaviour exhibited by the observed female of $P$. kirbii showed characteristics that seem to be related to the presence in the same nesting area of several provisioning females of S. continuus (ca. 30 during the period). The overlap of the resources needed by the two species, in particular bare soil and grasshoppers (Evans 1958, Benz 1959, Asìs et al. 1988), would account for the observed phenomenona. Notwithstanding the lack of a continuous recording of the activity of $P$. kirbii, we have stated that, at least in part, the wasp used two resources obtained by $S$. continuus females: emergence holes (as nests) and prey (as food for the larvae). By a slight shift in her behaviour, the female of $P$. kirbii may become a true kleptoparasite of $S$. continuus, at least for what prey is concerned (strictly speaking, emergence holes re-use is not a parasitic action). This strategy should allow reduced the expenditure of energy in digging a nest, but probably it does not reduce the time necessary to find the prey. In fact, we observed no more than one nest provisioned and completed per day, the commonest value found in many other Prionyx species studied (Evans 1958, Genise 1980, Grissell 1981).

Since re-using a pre-existing burrow (the emergence tunnels of $S$. continuus) evidently reduces the time spent to obtain a nest, prey-finding should be the activity that mainly determines the time necessary to complete a nest. In fact, attacking a $S$. continuus female to steal her prey is greatly more dangerous and time-consuming than re-using an emergence hole, which is no more used by any $S$. continuus females and only attracts the attention of the males (Asìs et al. 2006). Moreover, although territorial S. continuus males attack conspecific males and males of the mutillid parasite Nemka viduata (Pallas), they were never observed to interfere with the activity of $P$. kirbii. In conclusion, we may suppose that the females of $P$. kirbii prefer to gain time and energy colonizing an emerging tunnel of $S$. continuus; subsequently, they first try to feed their larvae at the expense of $S$. continuus (prey). Anyway, usually after having lost time by patrolling the $S$. continuus nesting area in search of a prey in an "easier" way, they resume their "normal" hunting activity. Re-using $S$. continuus nests does not seem to be related to similarity in nest architecture of the two species. In fact $P$. kirbii females have been observed to dig their nests even inside already pre-existing nests of bees of the genus 
Table 2. Observed facultative interspecific parasitism among different species of sphecoid wasps (Sphecidae and Crabronidae). The kind of behaviour of prey stealing is reported only for facultative kleptoparasitism.

\begin{tabular}{|c|c|c|c|c|}
\hline \multicolumn{2}{|c|}{ Facultative kleptoparasitism } & \multirow{2}{*}{$\begin{array}{l}\text { Prey of } \\
\text { the host }\end{array}$} & \multirow{2}{*}{$\begin{array}{l}\text { Kind of } \\
\text { parasitic } \\
\text { behaviour }\end{array}$} & \multirow[t]{2}{*}{ References } \\
\hline Parasite & Host & & & \\
\hline $\begin{array}{l}\text { Ammophila } \\
\text { kennedyi* (Murray) } \\
\text { [S] }\end{array}$ & $\begin{array}{l}\text { Ammophila urnaria } \\
\text { Dahlbom [S] }\end{array}$ & $\begin{array}{l}\text { Lepidoptera } \\
\text { larvae }\end{array}$ & $\begin{array}{l}\text { Theft of } \\
\text { provisions } \\
\text { from inside } \\
\text { nests }\end{array}$ & $\begin{array}{l}\text { Kurczewski et al. } \\
1992\end{array}$ \\
\hline $\begin{array}{l}\text { Ammophila urnaria* } \\
\text { [S] }\end{array}$ & $\begin{array}{l}\text { Ammophila kennedyi } \\
\text { [S], Podalonia } \\
\text { robusta (Cresson) [S] }\end{array}$ & $\begin{array}{l}\text { Lepidoptera } \\
\text { larvae, } \\
\text { Lepidoptera } \\
\text { larvae }\end{array}$ & $\begin{array}{l}\text { Theft of } \\
\text { provisions } \\
\text { from inside } \\
\text { nests }\end{array}$ & $\begin{array}{l}\text { Kurczewski et al. } \\
\text { 1992; } \\
\text { Kurczewski \& } \\
\text { Spofford } 1998\end{array}$ \\
\hline $\begin{array}{l}\text { Microbembex } \\
\text { monodonta ** (Say) } \\
\text { [B] }\end{array}$ & $\begin{array}{l}\text { Tachysphex } \\
\text { terminatus (F. Smith) } \\
\text { [C], Lyroda subita } \\
\text { Say [C], Bembix } \\
\text { pruinosa Fox [B], } \\
\text { Ammophila harti } \\
\text { (Fernald) [S] }\end{array}$ & $\begin{array}{l}\text { Orthoptera, } \\
\text { Diptera, } \\
\text { Diptera, } \\
\text { Lepidoptera } \\
\text { larvae }\end{array}$ & $\begin{array}{l}\text { Prey theft } \\
\text { outside the nest }\end{array}$ & $\begin{array}{l}\text { Kurczewski, } \\
\text { personal } \\
\text { communication, } \\
\text { quoted by Evans } \\
\text { 1966, p. 378; } \\
\text { Evans 1966, p. } \\
376,378\end{array}$ \\
\hline $\begin{array}{l}\text { Passaloecus corniger } \\
\text { Shuckard [P] } \\
{[\mathrm{P}]}\end{array}$ & $\begin{array}{l}\text { Passaloecus } \\
\text { singularis Dahlbom }\end{array}$ & Homoptera & $\begin{array}{l}\text { Theft of } \\
\text { provisions } \\
\text { from inside } \\
\text { nests }\end{array}$ & Danks 1970 \\
\hline $\begin{array}{l}\text { Passaloecus corniger } \\
\text { [P] }\end{array}$ & $\begin{array}{l}\text { Passaloecus gracilis } \\
\text { (Curtis) [P] }\end{array}$ & Homoptera & $\begin{array}{l}\text { Theft of } \\
\text { provisions } \\
\text { from inside } \\
\text { nests }\end{array}$ & $\begin{array}{l}\text { Corbet \& } \\
\text { Backhouse } 1975\end{array}$ \\
\hline $\begin{array}{l}\text { Passaloecus corniger } \\
{[\mathrm{P}]}\end{array}$ & $\begin{array}{l}\text { Passaloecus insignis } \\
\text { (Vander Linden) [P] }\end{array}$ & Homoptera & $\begin{array}{l}\text { Theft of } \\
\text { provisions } \\
\text { from inside } \\
\text { nests }\end{array}$ & $\begin{array}{l}\text { Corbet \& } \\
\text { Backhouse } 1975\end{array}$ \\
\hline $\begin{array}{l}\text { Passaloecus corniger } \\
{[\mathrm{P}]}\end{array}$ & $\begin{array}{l}\text { Psenulus atratus (F.) } \\
{[\mathrm{P}]}\end{array}$ & Homoptera & $\begin{array}{l}\text { Theft of } \\
\text { provisions } \\
\text { from inside } \\
\text { nests }\end{array}$ & $\begin{array}{l}\text { Chevalier } 1923, \\
\text { quoted by Evans } \\
\& \text { West-Eberhard } \\
1970 \text {, p. } 212\end{array}$ \\
\hline $\begin{array}{l}\text { Podalonia affinis* } \\
\text { (Kirby) [S] }\end{array}$ & $\begin{array}{l}\text { Ammophila sabulosa } \\
\text { L. [S] }\end{array}$ & $\begin{array}{l}\text { Lepidoptera } \\
\text { larvae }\end{array}$ & $\begin{array}{l}\text { Theft of } \\
\text { provisions } \\
\text { from inside } \\
\text { nests }\end{array}$ & $\begin{array}{l}\text { Field 1989, 1992; } \\
\text { Casiraghi et al. } \\
2003\end{array}$ \\
\hline $\begin{array}{l}\text { Ammophila kennedyi } \\
\text { [S] }\end{array}$ & $\begin{array}{l}\text { Podalonia robusta } \\
\text { [S] }\end{array}$ & $\begin{array}{l}\text { Lepidoptera } \\
\text { larvae }\end{array}$ & $\begin{array}{l}\text { Theft of } \\
\text { provisions } \\
\text { from inside } \\
\text { nests }\end{array}$ & $\begin{array}{l}\text { Kurczewski et al. } \\
1992\end{array}$ \\
\hline $\begin{array}{l}\text { Prionyx kirbii } \\
\text { Vander Linden [S] }\end{array}$ & $\begin{array}{l}\text { Stizus continuus } \\
\text { (Klug) }[\mathrm{B}]\end{array}$ & Orthoptera & $\begin{array}{l}\text { Theft of } \\
\text { provisions } \\
\text { from inside } \\
\text { nests; Prey } \\
\text { theft outside } \\
\text { the nest }\end{array}$ & Present study \\
\hline $\begin{array}{l}\text { Stictia signata (L.) } \\
\text { [B] }\end{array}$ & $\begin{array}{l}\text { Stictia heros } \\
\text { (Fabricius) [B] }\end{array}$ & Diptera & $\begin{array}{l}\text { Prey theft } \\
\text { outside the nest }\end{array}$ & Sheehan 1984 \\
\hline
\end{tabular}


Table 2 continued.

\begin{tabular}{|c|c|c|c|}
\hline \multicolumn{2}{|c|}{ Facultative brood parasitism } & \multirow{2}{*}{$\begin{array}{l}\text { Prey of } \\
\text { the host }\end{array}$} & \multirow[t]{2}{*}{ References } \\
\hline Parasite & Host & & \\
\hline $\begin{array}{l}\text { Ammophila } \\
\text { kennedyi*}^{\star}[\mathrm{S}]\end{array}$ & $\begin{array}{l}\text { Ammophila urnaria } \\
\text { [S] }\end{array}$ & $\begin{array}{l}\text { Lepidoptera } \\
\text { larvae }\end{array}$ & $\begin{array}{l}\text { Kurczewski et al. } \\
1992\end{array}$ \\
\hline $\begin{array}{l}\text { Ammophila urnaria* } \\
\text { [S] }\end{array}$ & $\begin{array}{l}\text { Ammophila kennedyi } \\
\text { [S] }\end{array}$ & $\begin{array}{l}\text { Lepidoptera } \\
\text { larvae }\end{array}$ & $\begin{array}{l}\text { Kurczewski et al. } \\
1992\end{array}$ \\
\hline $\begin{array}{l}\text { Podalonia affinis* } \\
\text { [S] }\end{array}$ & $\begin{array}{l}\text { Ammophila sabulosa } \\
\text { [S] }\end{array}$ & $\begin{array}{l}\text { Lepidoptera } \\
\text { larvae }\end{array}$ & Field 1989, 1992 \\
\hline $\begin{array}{l}\text { Liris niger } \\
\text { (Fabricius) [C] }\end{array}$ & $\begin{array}{l}\text { Sphex maxillosus } \\
\text { (Fabricius ) [S] }\end{array}$ & Orthoptera & Fabre 1914, p. 102 \\
\hline
\end{tabular}

$\mathrm{S}=$ Sphecidae; Crabronidae: $\mathrm{B}=$ Bembicinae, $\mathrm{P}=$ Pemphredoninae, $\mathrm{C}=$ Crabroninae; * species that appear both as facult ative kleptoparasites and brood parasites; ${ }^{* *}$ this species is a strict scavenger, according to Evans 1966, p. 376.

Halictus (Benz 1959). However, burrowing a new nest is very time-consuming activity: 22 minutes/cm, according to Benz (1959). Even if some amount of labour should be necessary to adapt a foreign nest, it could be worth doing it.

\subsection{Interspecific facultative parasitism in sphecoid wasps: distribution and occurrence}

Despite of the many studies devoted to intraspecific parasitism among solitary wasps (see Field 1992, for a review on its occurrence and performance in solitary Hymenoptera), very little information exists in literature about interspecific relationships (see Field 1992, for a brief review). Table 2 presents a summary of the actual knowledge on the occurrence of this phenomenon, restricted to the sphecid wasps (sensu Bohart \& Menke 1976; now the family is split into Crabronidae, Sphecidae and Ampulicidae) and considering only facultative parasitism. According to Field (1992), one may classify the different patterns of interspecific kleptoparasitic behaviour as in the intraspecific case (see Table 2 and Field 1992). In fact, the tactic does not change if the host is the same or a related species showing similar nesting habits. Field (1992) notes that facultative parasitism may occur even between distant species (up to bees vs. wasps), because the parasite only needs a resource similar to that employed in its normal and non-parasitical behav- iour. This seems to be true in particular for nest usurpation (without utilization of any other host resources). However, in the restricted field of facultative kleptoparasitism (and brood parasitism), sharing the same prey is not a sufficient condition and parasites and hosts have to be related species. In fact, there exists a considerable overlapping between nesting habits and phylogeny in sphecoid wasps: all the members of the same genus often use similar resources (Evans 1966, Bohart \& Menke 1976). Things seem to work differently in the case of obligate brood parasitism, for which only the recognition of the host nest is required. Parasitism will be performed later, in the absence of the host, when its nest will be reopened and its egg destroyed (e.g. Stizoides spp., Nysson spp.). On the contrary, facultative brood parasitism and facultative kleptoparasitism have probably followed a pathway different from that of obligate brood parasitism. Supporting this view, facultative kleptoparasitism has been observed more frequently in behaviourally related genera like Ammophila and Podalonia, whose members share similar resources (Table 2). In associations between related species, parasitic females know the characteristics of the host's nest and may recognize it more easily.

A second point concerns the overlap of food resources. For example, species of the genus Cerceris often nest in sympatry (Evans 1971, Hook 1987, Evans \& Hook 1986), but no records exist of interspecific kleptoparasitism or brood parasitism, even if interspecific nest usurpation 
was observed in some cases (Evans \& Hook 1986, Hook 1987). This is probably due to the large variety of prey hunted by the different species, which rarely overlap. On the other hand, genera that greatly overlap their prey spectrum and nesting areas, as Oxybelus and Bembix (Bohart \& Menke 1976), do not show any kind of reciprocal parasitism, probably because of the much different habits performed by these genera, which could prevent any efficient kleptoparasitism.

Unfortunately, data are too scarce to substantiate any hypothesis about the evolution of parasitic strategies in these wasps.

\subsection{The prepupa of Prionyx kirbii}

The description of the prepupa of $P$. kirbii is in reasonable agreement with the description of the mature larvae of the other species of the genus described: P. atratus (Lepeletier, 1845), P. thomae (Fabricius, 1775) (Evans \& Lin 1956) and P. viduatus (Christ, 1791) (Tsuneki \& Iida 1969). The prepupa of $P$. kirbii shares the following character states with the mature larvae of the three previously described species: (a) spiracles all in a single line, (b) cranium higher than wide, (c) mandibles without spinules on their upper surface and (d) thorax without welt-like elevations. However, the character states: (a) mandibles less than 2 times as long as maximum wide, and (b) galeae and maxillary palpi subequal in length (used by Evans and Lin (1956) to characterise the final larval stage of the tribe Sphecini, and the genus Prionyx Vander Linden, respectively), are not shown by $P$. viduatus and $P$. kirbii. Accordingly, they should not be used to characterise the respective taxa. In these latter species, the final larval stage has mandibles that are more than 2 times long than they are wide, and the galeae are longer than the maxillary palpi. Additionally, the prepupa of $P$. kirbii shares, with the mature larva of $P$. viduatus the following properties: (a) spinules of lacinial area not recurved, (b) an atrium with ridges forming small and irregular polygons, and c) inside of labium with ridges, as well as the characters described by Evans (1959) to characterise the Sphecinae (sensu Bohart \& Menke 1976).

Unlike the other described species of Prionyx, P. kirbii exhibits a clypeus with setae.
Acknowledgements. Thanks are due to the staff of Oficina Técnica, Viveros Municipales, Ayuntamiento de Valencia, for the field work permit, to Jesús Selfa (Universitat de Valencia) for the kind attention to the study and to S. F. Gayubo (University of Salamanca) for the identification of $P$. kirbii. Thanks are due to Henry Disney (University of Cambridge) for reading and correction of the text. CP and FA were in part supported by a three-years grant FIRB (Fondo per gli Investimenti per la Ricerca di Base) RBAU019H94-001 (2001) and (CP) by a one-year fellowship from the University of Milan. JT and JDA were supported by a grant from the Spanish Ministerio de Ciencia y Tecnología (BOS 20010864).

\section{References}

Asís, J. D., Tormos, J. \& Jiménez, R. 1988: Contribution to the study of the biology of Stizus continuus (Hymenoptera: Sphecidae). — Entomol. News 99: 199-206.

Asís, J. D., Tormos, J. \& Gayubo, S. F. 2006: Territorial dynamics and contest behaviour in the solitary wasp Stizus continuus (Hymenoptera : Apoidea : Crabronidae). - Behaviour: 143:83-104.

Benz, G. 1959: Beobachtungen über das brutbiologische Verhalten von Sphex albisectus, Lepeletier (Hym. Sphegidae). - Vierteljahrsschrift der Naturforschenden Gesellschaft in Zürich 104: 307-319.

Bohart, R. M. \& Menke, A. S. 1976: Sphecid Wasps of the World. A generic revision. - University of California Press, Berkeley, Los Angeles, London. 1 color plate, IX $+695 \mathrm{pp}$.

Casiraghi, M., Polidori, C., Ferreri, P., Preatoni, D. G., Andrietti, F., Martinoli, A. 2003: Does the distance among nest clusters affects reproductive success in Ammophila sabulosa (Hymenoptera, Sphecidae)? - Ethol. Ecol. Evol. 15: 329-341.

Corbet, S. A. \& Backhouse, M. 1975: Aphid-hunting wasps: a field study of Passaloecus. - Trans. R. Entomol. Soc. Lond. 127: 11-30.

Danks, H. V. 1970: Biology of some stem-nesting aculeate Hymenoptera. - Trans. R. Entomol. Soc. Lond. 122: 323-399.

Evans, H. E. 1958: Studies on the nesting behavior of digger wasps of the tribe Sphecini. Part I: Genus Priononyx Dahlbom. - Ann. Entomol. Soc. Am. 51: 177-186.

Evans, H. E. 1959: Studies on the larvae of digger wasps (Hymenoptera, Sphecidae). Part V: Conclusion. - Trans. Am. Entomol. Soc. 85: 137-191 + XVIII-XXIV plates.

Evans, H. E. 1966: The comparative ethology and evolution of the sand wasps. - Harvard University Press, Cambridge, Massachusetts. xvi $+526 \mathrm{pp}$.

Evans, H. E. 1971: Observations on nesting behavior of wasps of the tribe Cercerini (Hymenoptera: Sphecidae). - J. Kans. Entomol. Soc. 44: 500-523.

Evans, H. E. 1974: Digger wasps as colonizers of new habitat (Hymenoptera: Aculeata). - J. N.Y. Entomol. Soc. 82: 259-267.

Evans, H. E. 1987: Order Hymenoptera. — In: Stehr, F.W. 
(ed.), Immature Insects: pp. 597-710. Kendall/Hunt, Publishing Company, Dubuque, Iowa.

Evans, H. E. \& Lin, C. S. 1956: Studies on the larvae of digger wasps (Hymenoptera, Sphecidae) Part I: Sphecinae. - Trans. Am. Entomol. Soc. 81: 131-153 + IVIII plates.

Evans, H. E. \& West-Eberhard, M. J. 1970: The Wasps. Ann. Arbor: University of Michigan Press.

Evans, H. E. \& Hook, A. W. 1986: Nesting behavior of australian Cerceris digger wasps, with special reference to nest reutilization and nest sharing (Hymenoptera: Sphecidae). - Sociobiology 11: 275-302.

Fabre, J. H. 1914: Souvenirs Entomologiques (Première Série). - Delagrave, Paris. vii +375 pp.

Ferton, C. 1902: Notes détachées sur l'instinct des hyménoptères mellifères et ravisseurs ( $2^{\mathrm{e}}$ Série). - Ann. Soc. Ent. France 71: 499-531.

Field, J. 1989: Intraspecific parasitism and nesting success in the solitary wasp Ammophila sabulosa - Behaviour 110:23-46.

Field, J. 1992: Intraspecific parasitism as an alternative reproductive tactic in nest building wasps and bees. Biol. Rev. 67: 79-126.

Genise, J. F. 1980: Comportamiento de nidificación de Prionyx bifoveolatus (Taschb.) (Hymenoptera: Sphecidae). - Physis, Sección C, 39: 51-54.

Grissell, E. E. 1981: Nesting behavior of Prionyx "thomae” (Fabricius) (Hymenoptera: Sphecidae). - J. Kans. Entomol. Soc. 54: 16-21.

Hook, A. 1987: Nesting behaviour of Texas Cerceris digger wasps with emphasis on nest reutilization and nest sharing (Hymenoptera: Sphecidae). — Sociobiology 13: 93-118.
Kurczewski, F. E. \& Spofford, M. G. 1998: Alternative nesting strategies in Ammophila urnaria (Hymenoptera: Sphecidae). — J. Nat. Hist. 32: 99-106.

Kurczewski, F. E., O’Brien, M. F. \& Spofford, M. G. 1992: Nesting behavior of Podalonia robusta (Cresson) (Hymenoptera: Sphecidae). — J. Hym. Res. 1: 235239.

Matthews, R. W. 1983: Biology of a new Trypoxylon that utilizes nests of Microstigmus in Costa Rica (Hymenoptera: Sphecidae). — Pan-Pac. Entomol. 59: 152162.

McCorquodale, D. B. \& Thomson, C. E. 1988: A nest shared by the solitary wasps, Cerceris antipodes Smith and C. australis Saussure (Hymenoptera: Sphecidae). — J. Aust. Entomol. Soc. 27: 9-10.

Pulawski, W. J. 1999: Bibliography of Sphecidae. [www document] URL http://www.calacademy.org/research/entomology/Entomology_Resources/Hymenoptera/sphecidae/bibliography.pdf

Rosenheim, J. A. 1990: Density-dependent parasitism and evolution of aggregated nesting in the solitary Hymenoptera. - Ann. Entomol. Soc. Am. 83: 277-286.

Sheehan, W. 1984: Nesting biology of the sand wasp Stictia heros (Hymenoptera: Sphecidae: Nyssoninae) in Costa Rica. - J. Kans. Entomol. Soc. 57: 377-386.

Tsuneki, B. \& Iida, T. 1969: The biology of some species of the Formosan Sphecidae with descriptions of their larvae (Hymenoptera). - Etizenia 37: 1-21.

Wcislo, W. T. 1987: The roles of seasonality, host synchrony, and behaviour in the evolutions and distributions of nest parasites in Hymenoptera (Insecta), with special reference to bees (Apoidea). - Biol. Rev. Camb. Philos. Soc. 62: 415-443. 